\section{BRAZIULIAN JOURNAL \\ OF MEDICAL AND BIOLOGICAL RLSF.ARCH}

www.bjournal.com.br
ISSN 0100-879X

Volume 43 (04) 325-408

April 2010

BIOMEDICAL SCIENCES

AND

CLINICAL INVESTIGATION

Braz J Med Biol Res, March 2010, Volume 43(4) 356-358

Protective mechanism of agmatine pretreatment on RGC- 5 cells injured by oxidative stress

Y. lizuka, S. Hong, C.Y. Kim, W.I. Yang, J.E. Lee and G.J. Seong

The Brazilian Journal of Medical and Biological Research is partially financed by
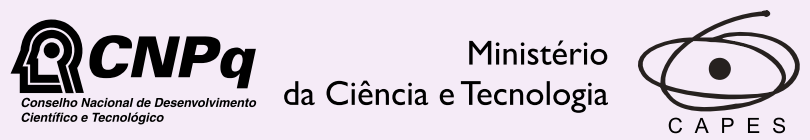

Ministério da Educação

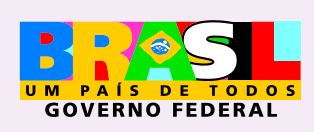

D FAPESP

Institutional Sponsors 


\title{
Protective mechanism of agmatine pretreatment on RGC-5 cells injured by oxidative stress
}

\author{
Y. lizuka1,2, S. Hong ${ }^{2}$, C.Y. Kim², W.I. Yang ${ }^{1,3}$, J.E. Lee ${ }^{4}$ and G.J. Seong ${ }^{2}$ \\ ${ }^{1}$ Brain Korea 21 Project for Medical Science, Yonsei University College of Medicine, Seoul, Korea \\ 2Department of Ophthalmology, Institute of Vision Research, \\ Yonsei University College of Medicine, Seoul, Korea \\ ${ }^{3}$ Department of Pathology, Yonsei University College of Medicine, Seoul, Korea \\ ${ }^{4}$ Department of Anatomy, Yonsei University College of Medicine, Seoul, Korea
}

\begin{abstract}
Agmatine has neuroprotective effects on retinal ganglion cells (RGCs) as well as cortical and spinal neurons. It protects RGCs from oxidative stress even when it is not present at the time of injury. As agmatine has high affinity for various cellular receptors, we assessed protective mechanisms of agmatine using transformed RGCs (RGC-5 cell line). Differentiated RGC-5 cells were pretreated with $100 \mu \mathrm{M}$ agmatine and consecutively exposed to $1.0 \mathrm{mM}$ hydrogen peroxide $\left(\mathrm{H}_{2} \mathrm{O}_{2}\right)$. Cell viability was determined by measuring lactate dehydrogenase $(\mathrm{LDH})$, and the effects of selective alpha 2-adrenergic receptor antagonist yohimbine (0-500 $\mathrm{nM}$ ) and N-methyl-D-aspartic acid (NMDA) receptor agonist NMDA (0-100 $\mu \mathrm{M})$ were evaluated. Agmatine's protective effect was compared to a selective NMDA receptor antagonist MK-801. After a 16-h exposure to $\mathrm{H}_{2} \mathrm{O}_{2}$, the LDH assay showed cell loss greater than $50 \%$, which was reduced to about $30 \%$ when agmatine was pretreated before injury. Yohimbine almost completely inhibited agmatine's protective effect, but NMDA did not. In addition, MK-801 (0-100 $\mu$ M) did not significantly attenuate the $\mathrm{H}_{2} \mathrm{O}_{2}$-induced cytotoxicity. Our results suggest that neuroprotective effects of agmatine on RGCs under oxidative stress may be mainly attributed to the alpha 2-adrenergic receptor signaling pathway.
\end{abstract}

Key words: Agmatine; Neuroprotection; Oxidative stress; Retinal ganglion cell

\section{Introduction}

Glaucoma is the leading cause of irreversible blindness worldwide. Although elevated intraocular pressure has been known as a major risk factor for the development and progression of glaucoma, oxidative stress is also associated with glaucomatous visual field deterioration (1-3). Retinal ganglion cells (RGCs) are susceptible to oxidative stress (3-5). As glaucomatous damages are mostly irreversible, many glaucoma researchers are searching for a neuroprotective strategy for RGCs.

Agmatine is a primary amine, which is formed by decarboxylation of L-arginine in the mammalian brain. Agmatine has high affinity for various cellular receptors. It is an agonist for alpha 2-adrenergic and imidazoline receptors and an antagonist for $\mathrm{N}$-methyl-D-aspartic acid (NMDA) receptors (6-8). Agmatine has neuroprotective effects against cortical and spinal neuronal injuries (9-11). It also protects RGCs from hypoxic damage (12). Even when agmatine is not present at the time of injury, it seems to protect RGCs by later blocking cellular death induced by oxidative stress (13). However, the precise protective mechanisms of agmatine pretreatment have not been well established.

We investigated the mechanisms of action of agmatine pretreatment on RGCs under oxidative stress using transformed RGCs (RGC-5 cell line).

\section{Material and Methods}

\section{Cell culture and agmatine pretreatment}

RGC-5 cells, which belong to a transformed RGC line developed from postnatal Sprague-Dawley rats, were cultured in Dulbecco's modified Eagle's medium (DMEM; Gibco, USA) plus 10\% heat-inactivated fetal bovine serum

Correspondence: G.J. Seong, Department of Ophthalmology, Institute of Vision Research, Yonsei University College of Medicine, 712 Eonjuro, Gangnam-gu, Seoul 135-720, Korea. Fax: +82-2-3463-1049. E-mail: gjseong@yuhs.ac 
(FBS; Gibco), $100 \mathrm{U} / \mathrm{mL}$ penicillin, and $100 \mu \mathrm{g} / \mathrm{mL}$ streptomycin (Gibco). For differentiation, the cells were incubated with $1.0 \mu \mathrm{M}$ staurosporine (Sigma-Aldrich, USA) for $6 \mathrm{~h}$; and then they were cultured in 10\% FBS-DMEM for another 3 days (13).

After differentiation, the cells were pretreated with $100 \mu \mathrm{M}$ agmatine (Sigma-Aldrich) in serum-free DMEM for $2 \mathrm{~h}$ (13), and then rinsed with phosphate-buffered saline (PBS; Gibco). Control cells were incubated in serum-free DMEM.
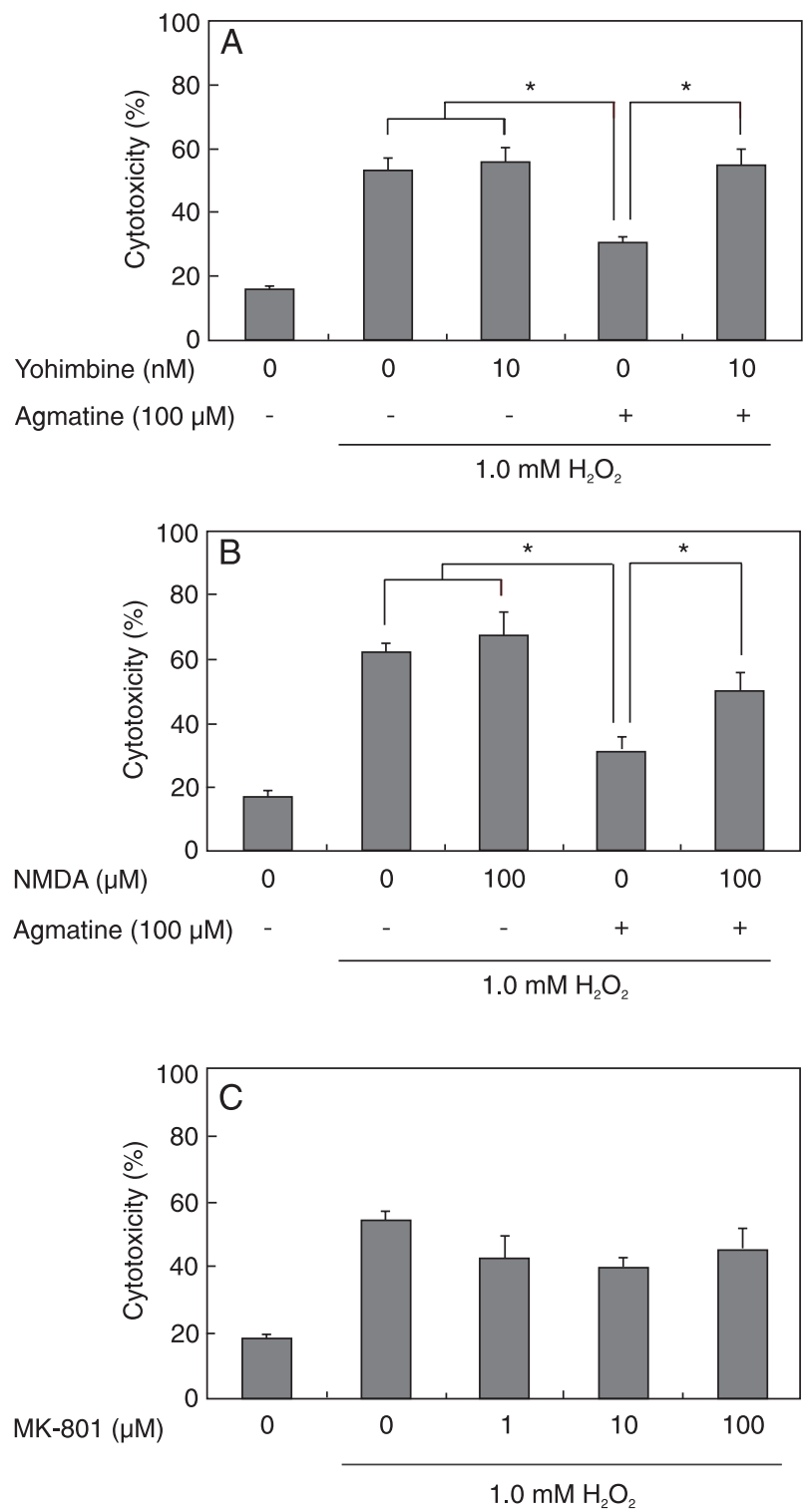

Figure 1. Determination of $\mathrm{H}_{2} \mathrm{O}_{2}$ cytotoxicity by the lactate dehydrogenase assay. Differentiated RGC- 5 cells were pretreated with $100 \mu \mathrm{M}$ agmatine and then exposed to oxidative stress with yohimbine (A) or N-methyl-D-aspartic acid (NMDA) (B). The cells were also treated with MK-801 (C). Panels $A$ and $B$, ${ }^{*} \mathrm{P}<0.05$ (one-way ANOVA followed by post hoc comparisons).

\section{Oxidative stress with agonist/antagonist}

After agmatine $(100 \mu \mathrm{M})$ pretreatment for $2 \mathrm{~h}$, the cells were exposed to $1.0 \mathrm{mM}$ hydrogen peroxide $\left(\mathrm{H}_{2} \mathrm{O}_{2}\right.$; SigmaAldrich) for $16 \mathrm{~h}$ (13). The mechanisms of action of agmatine pretreatment were investigated using the specific alpha 2-adrenergic receptor antagonist yohimbine (0-500 nM; Sigma-Aldrich), and NMDA receptor agonist NMDA (0-100 $\mu \mathrm{M}$; Calbiochem, USA). In addition, the effect of agmatine was compared to that of MK-801 (0-100 $\mu \mathrm{M}$; Sigma-Aldrich), a selective NMDA receptor antagonist.

\section{Cytotoxicity assay}

Cell viability was determined by measuring lactate dehydrogenase (LDH; CytoTox 96 ${ }^{\circledR}$ Non-Radioactive Cytotoxicity Assay Kit; Promega, USA) according to manufacturer instruction. Briefly, the LDH released from injured cells into the culture medium was reacted with tetrazolium salt. The red formazan product was measured at $490 \mathrm{~nm}$ using an ELISA plate reader (Vmax; Molecular Device, USA). Cytotoxicity was calculated as the proportion of injured cells to the total cell population (14). Data are reported as means \pm SEM.

\section{Statistical analysis}

Data were analyzed by one-way ANOVA, followed by post hoc comparisons (Student-Newman-Keuls) using the Statistical Package for Social Sciences (SPSS) program for Windows, version 12.0 (SPSS Inc., USA). P values below 0.05 were considered to be significant.

\section{Results}

Differentiated RGC-5 cells were pretreated with 100 $\mu \mathrm{M}$ agmatine for $2 \mathrm{~h}$, and then exposed to $1.0 \mathrm{mM} \mathrm{H}_{2} \mathrm{O}_{2}$ for $16 \mathrm{~h}$ for induction of oxidative stress. After agmatine pretreatment, the cytotoxicity of $\mathrm{H}_{2} \mathrm{O}_{2}$ declined from above 50 to approximately $30 \%$ (Figure $1 \mathrm{~A}, \mathrm{~B}$ ).

Neither yohimbine nor NMDA, at any concentration, had any significant effect on oxidative stress-induced cell death (data not shown); $10 \mathrm{nM}$ yohimbine and $100 \mu \mathrm{M}$ NMDA were used for further experiments. While yohimbine almost completely blocked the protective effects of agmatine pretreatment (Figure 1A), NMDA did not (Figure 1B).

To evaluate the contribution of NMDA receptor signaling, the protective effect of agmatine was compared to that of MK-801. MK-801 did not significantly affect the $\mathrm{H}_{2} \mathrm{O}_{2}$ induced cytotoxicity of RGC-5 cells (Figure 1C).

\section{Discussion}

Agmatine is known to be an agonist for alpha 2-adrenergic and imidazoline receptors as well as an antagonist of NMDA receptors (6-8). Wheeler and WoldeMussie (15) and Kalapesi et al. (16) studied the alpha 2-adrenergic receptors of human ganglion cells and the RGC-5 cell line. They dem- 
onstrated the presence of alpha $2 \mathrm{~A}$-adrenergic receptors on both undifferentiated and succinyl concanavalin-A differentiated RGC-5s. They also showed a higher expression of alpha 2A-adrenergic receptors on 7-day differentiated RGC-5 cells compared to the undifferentiated and early differentiated cells. In addition, RGCs also expressed NMDA glutamate receptors.

In the present study, the protective effects of agmatine pretreatment on RGC-5s under oxidative stress were completely abolished by $10 \mathrm{nM}$ yohimbine but only partially decreased by $100 \mu \mathrm{M}$ NMDA. Even the powerful NMDA antagonist MK-801 did not reduce the RGC-5 cell death induced by $\mathrm{H}_{2} \mathrm{O}_{2}$. These results suggest that agmatine pretreatment may rescue RGCs from oxidative stress mainly through alpha 2-adrenergic signaling rather than through the NMDA receptor pathway.

We have demonstrated that agmatine pretreatment has anti-apoptotic effects on differentiated RGC-5s under

\section{References}

1. Neufeld AH. Nitric oxide: a potential mediator of retinal ganglion cell damage in glaucoma. Surv Ophthalmol 1999; 43 (Suppl 1): S129-S135.

2. Ferreira SM, Lerner SF, Brunzini R, Evelson PA, Llesuy SF. Oxidative stress markers in aqueous humor of glaucoma patients. Am J Ophthalmol 2004; 137: 62-69.

3. Kumar DM, Agarwal N. Oxidative stress in glaucoma: a burden of evidence. J Glaucoma 2007; 16: 334-343.

4. Mainster MA. Light and macular degeneration: a biophysical and clinical perspective. Eye 1987; 1 (Part 2): 304-310.

5. Organisciak DT, Darrow RM, Barsalou L, Darrow RA, Kutty RK, Kutty G, et al. Light history and age-related changes in retinal light damage. Invest Ophthalmol Vis Sci 1998; 39: 1107-1116.

6. Reynolds IJ. Arcaine uncovers dual interactions of polyamines with the $\mathrm{N}$-methyl-D-aspartate receptor. J Pharmacol Exp Ther 1990; 255: 1001-1007.

7. Li G, Regunathan S, Barrow CJ, Eshraghi J, Cooper R, Reis DJ. Agmatine: an endogenous clonidine-displacing substance in the brain. Science 1994; 263: 966-969.

8. Piletz JE, Chikkala DN, Ernsberger P. Comparison of the properties of agmatine and endogenous clonidine-displacing substance at imidazoline and alpha-2 adrenergic receptors. J Pharmacol Exp Ther 1995; 272: 581-587.

9. Gilad GM, Gilad VH. Accelerated functional recovery and oxidative stress (13). In the present study, its protective mechanisms were investigated. Considering the many biological functions of agmatine, this study is not sufficient since its focus was limited to alpha 2-adrenergic and NMDA receptor pathways. Further experiments are needed to fully understand the neuroprotective mechanisms of agmatine pretreatment.

The neuroprotective mechanisms of agmatine pretreatment on RGCs under oxidative stress in vitro may be mainly associated with the alpha 2-adrenergic receptor signaling pathway.

\section{Acknowledgments}

The authors thank Alcon Research, Ltd., for providing the RGC-5 cell line. Research supported by the Korea Research Foundation Grant funded by the Korean Government (MOEHRD; KRF-2007-314-E00134). neuroprotection by agmatine after spinal cord ischemia in rats. Neurosci Lett 2000; 296: 97-100.

10. Feng Y, Piletz JE, Leblanc MH. Agmatine suppresses nitric oxide production and attenuates hypoxic-ischemic brain injury in neonatal rats. Pediatr Res 2002; 52: 606-611.

11. Kim JH, Yenari MA, Giffard RG, Cho SW, Park KA, Lee JE. Agmatine reduces infarct area in a mouse model of transient focal cerebral ischemia and protects cultured neurons from ischemia-like injury. Exp Neurol 2004; 189: 122-130.

12. Hong S, Lee JE, Kim CY, Seong GJ. Agmatine protects retinal ganglion cells from hypoxia-induced apoptosis in transformed rat retinal ganglion cell line. BMC Neurosci 2007; 8: 81.

13. lizuka Y, Hong S, Kim CY, Kim SK, Seong GJ. Agmatine pretreatment protects retinal ganglion cells (RGC- 5 cell line) from oxidative stress in vitro. Biocell 2008; 32: 245-250.

14. Hong S, Kim CY, Lee JE, Seong GJ. Agmatine protects cultured retinal ganglion cells from tumor necrosis factoralpha-induced apoptosis. Life Sci 2009; 84: 28-32.

15. Wheeler LA, WoldeMussie E. Alpha-2 adrenergic receptor agonists are neuroprotective in experimental models of glaucoma. Eur J Ophthalmol 2001; 11 (Suppl 2): S30-S35.

16. Kalapesi FB, Coroneo MT, Hill MA. Human ganglion cells express the alpha-2 adrenergic receptor: relevance to neuroprotection. Br J Ophthalmol 2005; 89: 758-763. 